Check for updates

Cite this: J. Mater. Chem. B, 2019, 7, 2557

Received 14th January 2019,

Accepted 3rd March 2019

DOI: $10.1039 / c 9 t b 00079 h$

rsc.li/materials-b

\title{
Detection of hypochlorous acid fluctuation via a selective near-infrared fluorescent probe in living cells and in vivo under hypoxic stress $\dagger$
}

\author{
Yan Huang, $\ddagger^{\mathrm{ab}} \mathrm{Na} \mathrm{He}, \ddagger^{\mathrm{bc}}$ Yude Wang, ${ }^{\mathrm{bc}}$ Liangwei Zhang, ${ }^{\mathrm{b}}$ Qi Kang, ${ }^{\mathrm{a}}$ \\ Yunqing Wang, ${ }^{b}$ Dazhong Shen, (D) ${ }^{a}$ Jaebum Choo (D) *d and Lingxin Chen (D) *be
}

\begin{abstract}
Hypoxic stress is a common concern in medicine and biology, which can induce the cellular injury and death by excess production of reactive oxygen species (ROS). Hypochlorous acid ( $\mathrm{HOCl}$ ), one of the ROS, plays a crucial role in the oxidative damage to tissue proteins in the pathogenesis of various diseases. Therefore, excess production of $\mathrm{HOCl}$ might be an important factor for the damage caused by hypoxic stress. However, most of the present methods cannot meet the demand of real-time detection on account of the labile and reactive chemical properties of $\mathrm{HOCl}$. Herein, we designed a near-infrared fluorescent probe, $\mathrm{Cy}-\mathrm{HOCl}$, for the selective imaging of $\mathrm{HOCl}$ in cells and in vivo. $\mathrm{Cy}-\mathrm{HOCl}$ includes two moieties: a 4-amino-3-nitrophenol group as the response unit and a near-infrared heptamethine cyanine fluorophore as the fluorescent modulator. $\mathrm{Cy}-\mathrm{HOCl}$ exhibits excellent selectivity and sensitivity towards the detection of $\mathrm{HOCl}$. The hypoxic response behavior of $\mathrm{Cy}-\mathrm{HOCl}$ is evaluated in cells to clarify the relationship between $\mathrm{HOCl}$ and hypoxia. The probe is also applied to measure $\mathrm{HOCl}$ in ex vivodissected organs of an acute ischemia mouse model as well as for real-time monitoring the changes of $\mathrm{HOCl}$ in the hypoxic zebrafish model.
\end{abstract}

\section{Introduction}

Hypoxic stress is a common concern in medicine and biology, which can induce excess production of $\operatorname{ROS}^{1}$ to cause cellular injury and death. ${ }^{2,3}$ ROS is a collective term that includes oxygen radicals, such as hydroxyl radical $\left(\mathrm{OH}^{\bullet}\right)$, superoxide anion $\left(\mathrm{O}_{2}{ }^{\bullet-}\right)$ and peroxyl radical $\left(\mathrm{RO}_{2}{ }^{\bullet}\right)$, as well as some non-radical derivatives of oxygen $\left(\mathrm{O}_{2}\right)$ such as ozone $\left(\mathrm{O}_{3}\right)$, hydrogen peroxide $\left(\mathrm{H}_{2} \mathrm{O}_{2}\right)$ and hypochlorous acid ( $\left.\mathrm{HOCl}\right)$. HOCl partially dissociates into hypochlorite anion in a solution at physiological $\mathrm{pH}^{4}$

\footnotetext{
${ }^{a}$ College of Chemistry, Chemical Engineering and Materials Science, Key Laboratory of Molecular and Nano Probes, Ministry of Education, Shandong Normal University, Jinan 250014, China. E-mail: kangqi@sdnu.edu.cn

${ }^{b}$ CAS Key Laboratory of Coastal Environmental Processes and Ecological Remediation, The Research Center for Coastal Environmental Engineering and Technology, Yantai Institute of Coastal Zone Research, Chinese Academy of Sciences, Yantai 264003, China. E-mail: lxchen@yic.ac.cn

${ }^{c}$ Medicine Research Center, Institute of Molecular Medicine, Binzhou Medical University, Yantai 264003, China

${ }^{d}$ Department of Chemistry, Chung-Ang University, Seoul 06974, South Korea. E-mail:jbchoo@cau.ac.kr

${ }^{e}$ College of Chemistry and Chemical Engineering, Qufu Normal University, Qufu 273165, China

$\dagger$ Electronic supplementary information (ESI) available. See DOI: 10.1039/ c9tb00079h

\# These authors contributed equally.
}

Within a definite concentration range, $\mathrm{HOCl}$ can act as an effective bactericide due to its strong oxidizability. On the other hand, $\mathrm{HOCl}$ is also a common byproduct of cellular metabolism, which plays a vital role in many biological processes. ${ }^{5,6}$ In organisms, HOCl can be synthesized from hydrogen peroxide and chloride ions under the catalysis of myeloperoxidase (MPO), which is mostly stored in azurophilic granules of leukocytes (including macrophages, neutrophils and monocytes). ${ }^{7,8} \mathrm{HOCl}$ is extremely reactive and non-selectively modifies all biomolecules, especially proteins, giving rise to significant inactivation of proteins and severe damage to cells. ${ }^{9}$ The additional generation of $\mathrm{HOCl}$ can give rise to inflammation-associated injury, such as lung injury, ${ }^{10}$ hepatic ischemia reperfusion injury, ${ }^{11}$ rheumatoid arthritis ${ }^{12}$ and atherosclerosis, ${ }^{13}$ via the same processes utilized in the destruction of the invading microorganisms. More importantly, the increasing level of ROS in cells under hypoxic stress has been proved, ${ }^{1}$ but the relationship between hypoxia and HOCl has not been fully demonstrated to date. We suppose the phenomenon of intracellular $\mathrm{HOCl}$ changes is one of the major sources of damage under hypoxic stress. Therefore, establishing an ideal and simple fluorescence method for detection of $\mathrm{HOCl}$ to explore the relationship between $\mathrm{HOCl}$ and hypoxia is still necessary.

To date, detailed research of the oxidation biology of $\mathrm{HOCl}$ has been restricted by the difficulty in monitoring such a small 
reactive oxygen metabolite in real time, motivating investigators to develop a selective and sensitive tool for the tracking of $\mathrm{HOCl}$, to provide reliable and accurate $\mathrm{HOCl}$ signals both in vivo and in vitro. Due to its outstanding high sensitivity, selectivity, and real-time analysis, fluorescence imaging is an attractive method for monitoring biomolecules in living systems. Previously, a number of bioanalytical methods for the detection of $\mathrm{HOCl}$ have been developed. ${ }^{14}$ Most were developed on the basis of the conjugation of an organic fluorophore with a HOCl-recognizing moiety, such as $p$-methoxyphenol, $p$-aminophenyl ether, thiol, $\mathrm{N}$-heterocyclic carbene borane, dibenzoyl hydrazine, hydroxamic acid, ferrocene and oxim derivatives. ${ }^{15-39}$ Although these fluorescent probes can detect and quantify $\mathrm{HOCl}$ concentrations in biological samples by the changes of fluorescence intensity, the detection is often hampered by background fluorescence due to the excitation and emission wavelengths of these probes locating in the visible region; the method is not suitable for imaging in deep structures. Near-infrared (NIR) fluorescence can deeply penetrate tissue and effectively avoid background noise. ${ }^{40}$ The existing NIR fluorescence probe for detection of $\mathrm{HOCl}$ is limited by the "on-off" fluorescence response leading to a poor signal-to-noise ratio. ${ }^{41}$ Therefore, imaging of $\mathrm{HOCl}$ in living cells and animals using a desirable "off-on" NIR fluorescent probe is another considerable issue to be addressed.

Herein, we design and synthesize the "off-on" NIR fluorescent probe $\mathrm{Cy}-\mathrm{HOCl}$ for the detection of $\mathrm{HOCl}$ in living cells and in vivo. Cy-HOCl includes two moieties: a 4-amino-3nitrophenol group as the response unit and a near-infrared heptamethine cyanine fluorophore as the fluorescence modulator. The fluorescence of $\mathrm{Cy}-\mathrm{HOCl}$ is quenched due to photoinduced electron transfer (PET) between response unit and fluorophore. The response unit can be specifically eliminated with $\mathrm{HOCl}$ and induce the fluorescence to "turn on". The probe exhibited a specific response for $\mathrm{HOCl}$ and provided high sensitivity and selectivity toward $\mathrm{HOCl}$ in cells. The results demonstrated that the level of $\mathrm{HOCl}$ increased in hypoxic cells, hypoxic zebrafish models, and acute liver ischemia mice models. To the best of our knowledge, $\mathrm{Cy}-\mathrm{HOCl}$ was the first fluorescence tool for imaging and quantifying the relationship between the level of HOCl and hypoxic stress in cells and in vivo. We also confirmed that the hypoxic stress not only caused the apoptosis of cells, but also the damage of tissue. We anticipate that our $\mathrm{Cy}-\mathrm{HOCl}$ probe will be a powerful tool for investigating the pathological and physiological roles of $\mathrm{HOCl}$ in living cells and in vivo.

\section{Experimental}

\subsection{Synthetic routes of probe $\mathrm{Cy}-\mathrm{HOCl}$}

2.1.1 Synthesis of $\mathbf{N}$-ethyl-2,3,3-trimethylindolinium iodide 3. 2,3,3-Trimethyl-3H-indolenine (12 g, $75 \mathrm{mmol}$ ) and iodoethane (11.5 g, $75 \mathrm{mmol}$ ) were mixed in $40 \mathrm{~mL}$ anhydrous acetonitrile in a $250 \mathrm{~mL}$ round flask. The mixture was refluxed for $12 \mathrm{~h}$, then removed from heat and cooled. The precipitate was filtered through a Büchner funnel and the solid product was washed with diethyl ether and dried in vacuum to afford a pink product (10.9 g, yield: 90\%). ${ }^{1} \mathrm{H}$ NMR (DMSO-d $6,500 \mathrm{MHz}$ ) $\delta(\mathrm{ppm}): 8.04-8.02(\mathrm{t}, 1 \mathrm{H}), 7.91-7.89(\mathrm{t}, 1 \mathrm{H}), 7.66-7.62(\mathrm{~m}, 2 \mathrm{H})$, 4.57-4.53 (m, 2H), $2.92(\mathrm{~s}, 3 \mathrm{H}), 1.58(\mathrm{~s}, 6 \mathrm{H}), 1.49-1.46(\mathrm{t}, 3 \mathrm{H})$. ${ }^{13} \mathrm{C}$ NMR (DMSO-d 6 , $\left.125 \mathrm{MHz}\right) \delta$ (ppm): 196.5, 142.4, 141.1, 129.4, 124.1, 115.8, 54.6, 43.8, 40.1, 22.4, 14.9, 13.3. MS (ESI $\left.{ }^{+}\right)$: $m / z \mathrm{C}_{13} \mathrm{H}_{18} \mathrm{~N}^{+}$calcd 188.1434, found $\left[\mathrm{M}^{+}\right]$188.1435.

2.1.2. Synthesis of compound 2. A solution of $40 \mathrm{~mL}$ of anhydrous $\mathrm{N}, \mathrm{N}$-dimethylformamide (DMF) and $40 \mathrm{~mL}$ of anhydrous $\mathrm{CH}_{2} \mathrm{Cl}_{2}$ was placed in a $250 \mathrm{~mL}$ round-bottom flask. The solution was chilled to $-10{ }^{\circ} \mathrm{C}$ and then stirred for $20 \mathrm{~min}$. Phosphorus oxychloride $\left(37 \mathrm{~mL}\right.$ ) in $35 \mathrm{~mL}$ of anhydrous $\mathrm{CH}_{2} \mathrm{Cl}_{2}$ was added dropwise into the above solution through a constant pressure drop of liquid funnel. 4-Cyclohexanone (10 g, $101.9 \mathrm{mmol})$ was added into the mixture in batches; the solution immediately changed from colorless to yellow. Then the solution was slowly heated to $45{ }^{\circ} \mathrm{C}$ for $3 \mathrm{~h}$, cooled, poured over ice, and allowed to stand overnight. The yellow solid was collected through a Büchner funnel and dried in vacuum (12.9 g, yield: 85\%). ${ }^{1} \mathrm{H}$ NMR (DMSO-d $\left.{ }_{6}, 500 \mathrm{MHz}\right) \delta(\mathrm{ppm}): 8.12(\mathrm{~s}, 1 \mathrm{H}), 8.08$ (s, 1H), $7.14(\mathrm{~s}, 1 \mathrm{H}), 2.38-2.71(\mathrm{~m}, 2 \mathrm{H}), 2.53-2.45(\mathrm{~m}, 2 \mathrm{H})$, 2.28-2.26 (m, 2H). ${ }^{13} \mathrm{C}$ NMR (DMSO-d, $\left.125 \mathrm{MHz}\right) \delta$ (ppm): 191.8, 162.9, 148.5, 145.7, 142.4, 37.2, 31.7, 30.6. MS (ESI $\left.{ }^{-}\right)$: $\mathrm{m} / \mathrm{z}_{8} \mathrm{H}_{9} \mathrm{ClO}_{2}$ calcd 172.0553, found $[\mathrm{M}-\mathrm{H}]^{-} 171.0481$.

2.1.3. Synthesis of compound 1. Compounds $3(0.84 \mathrm{~g}$, $2 \mathrm{mmol})$ and $2(0.17 \mathrm{~g}, 1 \mathrm{mmol})$ were redissolved in $100 \mathrm{~mL}$ mixed solution of $n$-butyl alcohol and benzene $(7: 3, \mathrm{v} / \mathrm{v})$ in a $250 \mathrm{~mL}$ round flask, refluxed for $3 \mathrm{~h}$, and dried in vacuum to obtain a green solid. The crude product was purified by silica gel chromatography using EtOAc/ $\mathrm{CH}_{3} \mathrm{OH}(8: 1, \mathrm{v} / \mathrm{v})$ as eluent to afford compound 1 as green solid ( $0.682 \mathrm{~g}, 70 \%$ yield). ${ }^{1} \mathrm{H}$ NMR $\left(\mathrm{CDCl}_{3}-\mathrm{d}_{1}, 500 \mathrm{MHz}\right) \delta(\mathrm{ppm}): 8.43-8.40(\mathrm{~d}, 1 \mathrm{H}), 7.41-7.39$ $(\mathrm{m}, 2 \mathrm{H}), 7.28-7.15(\mathrm{~m}, 6 \mathrm{H}), 6.09-6.07(\mathrm{~d}, 2 \mathrm{H}), 5.01(\mathrm{~s}, 1 \mathrm{H})$, 4.14-4.15 (m, 4H), 3.01-2.97 (m, 4H), 2.68-2.63 (m, 2H), 2.04 (m, 6H), $1.79(\mathrm{~m}, 6 \mathrm{H}), 1.42-1.39(\mathrm{~m}, 3 \mathrm{H}), 1.27-1.24(\mathrm{~m}, 3 \mathrm{H})$. ${ }^{13} \mathrm{C}$ NMR (DMSO-d $\left.6,125 \mathrm{MHz}\right) \delta$ (ppm): 172.2, 171.2, 150.3, 144.6, 141.6, 141.2, 128.9, 125.5, 122.3, 110.9, 100.6, 60.4, 49.5, 39.9, 38.0, 34.2, 28.1, 21.1, 14.2, 12.5. $\mathrm{MS}\left(\mathrm{ESI}^{+}\right): m / z \mathrm{C}_{34} \mathrm{H}_{40} \mathrm{ClN}_{2}{ }^{+}$ calcd 511.3137, found $\left[\mathrm{M}^{+}\right]$511.3137.

2.1.4. Synthesis of probe Cy-HOCl. 4-Amino-3-nitrophenol $(0.77 \mathrm{~g}, 5.00 \mathrm{mmol})$ and $\mathrm{NaH}(60 \%$ in mineral oil, $0.208 \mathrm{~g}$, $5.00 \mathrm{mmol}$ ) were dissolved in anhydrous DMF $(30 \mathrm{~mL})$. The mixture was stirred at $25{ }^{\circ} \mathrm{C}$ for $15 \mathrm{~min}$ under $\mathrm{Ar}$ atmosphere. Then, compound $1(0.424 \mathrm{~g}, 0.83 \mathrm{mmol})$ was introduced into the above mixture. The reaction mixture was further stirred for $24 \mathrm{~h}$ at $25{ }^{\circ} \mathrm{C}$. The solvent was removed under reduced pressure and the crude product was purified by silica gel chromatography using EtOAc/ $\mathrm{CH}_{3} \mathrm{OH}(4: 1, \mathrm{v} / \mathrm{v})$ as eluent to afford probe $\mathrm{Cy}-\mathrm{HOCl}$ as a green solid (0.293 g, 50\% yield). ${ }^{1} \mathrm{H}$ NMR ( $\left.\mathrm{CH}_{3} \mathrm{DO}, 500 \mathrm{MHz}\right) \delta(\mathrm{ppm}): 8.53$ (s, 1H), 8.00-7.97 (d, 1H), 7.66-7.36 (m, 6H), 7.26-7.21 (m, 2H), 7.10-6.84 (m, 2H), 6.65-6.60 (m, 3H), 6.19-6.16 (m, 2H), 4.15-4.14, (m, 4H), 2.75-2.74 (m, 4H), $1.92(\mathrm{~m}, 6 \mathrm{H}), 1.41-1.28(\mathrm{~m}, 14 \mathrm{H})$. ${ }^{13} \mathrm{C}$ NMR $\left(\mathrm{CH}_{3} \mathrm{DO}, 125 \mathrm{MHz}\right) \delta$ (ppm): 171.9, 163.4, 149.7, 142.2, 141.7, 141.6, 141.1, 130.1, 129.4, 128.4, 124.8, 124.6, 122.0, 121.6, 121.0, 110.3, 108.7, 99.4, 65.2, 38.7, 30.3, 26.6, 23.8, 21.0, 10.9. MS (ESI ${ }^{+}$): $m / z \mathrm{C}_{40} \mathrm{H}_{45} \mathrm{~N}_{4} \mathrm{O}_{3}{ }^{+}$calcd 629.3486, found $\left[\mathrm{M}^{+}\right] 629.5806$. 


\subsection{Cytotoxicity of $\mathrm{Cy}-\mathrm{HOCl}$}

The cytotoxicity of probe Cy-HOCl was assessed by MTT assay. Human normal liver cells (LO2 cells) were seeded into a 96-well cell culture plate at a final density of $8 \times 10^{3}$ cells per well. Different concentrations of Cy-HOCl $(0.1 \mu \mathrm{M}, 1 \mu \mathrm{M}, 10 \mu \mathrm{M}$, and $100 \mu \mathrm{M})$ were added to the wells. The cells were incubated for $24 \mathrm{~h}$ at $37{ }^{\circ} \mathrm{C}$ under $5 \% \mathrm{CO}_{2}$. Subsequently, MTT was added to each well (final concentration $5 \mathrm{mg} \mathrm{mL}^{-1}$ ) for an additional $4 \mathrm{~h}$ incubation at $37{ }^{\circ} \mathrm{C}$ under $5 \% \mathrm{CO}_{2}$, then formazan crystals formed, which were dissolved in $150 \mu \mathrm{L}$ DMSO. The amount of MTT formazan was quantified by absorbance (OD) at $570 \mathrm{~nm}$ using a microplate reader (Tecan, Austria). Calculation of $\mathrm{IC}_{50}$ values were done according to Huber and Koella. The results are the mean standard deviation of six separate measurements.

\subsection{Zebrafish line imaging}

Four to five pairs of zebrafish were placed in crossing tanks for spawning overnight. Embryos settled to the bottom of the tank, then were collected using a sieve and transferred to Petri dishes for culture. They were screened, incubated at $27{ }^{\circ} \mathrm{C}, 0.4 \% \mathrm{CO}_{2}$ and grown in egg water $\left(10 \% \mathrm{NaCl} ; 1.63 \% \mathrm{MgSO}_{4} \cdot 7 \mathrm{H}_{2} \mathrm{O} ; 0.4 \% \mathrm{CaCl}_{2}\right.$; $0.3 \% \mathrm{KCl}$ ). At $22 \mathrm{~h}$ post-fertilization, PTU was added to prevent melanin formation and yield optically transparent fish. $3 \mathrm{~d}$ postfertilization, the embryos were seeded to into 96 well plates at 1 embryo per well. The embryos were soaked in $5 \mu \mathrm{M}$ of $\mathrm{Cy}-\mathrm{HOCl}$ for $30 \mathrm{~min}$ and were imaged for uptake using confocal laser scanning microscope imaging (Japan Olympus Co., Ltd) at $405 \mathrm{~nm}$.

\subsection{Liver ischemia mice model and imaging of liver ischemia tissue sections}

Six to eight-week-old BALB/c mice were obtained from Binzhou Medical University. All experimental procedures were conducted in conformity with institutional guidelines for the care and use of laboratory animals; protocols were approved by the Institutional Animal Care and Use Committee of Binzhou Medical University, Yantai, China. Approval Number: No. BZ2014-102R. Mice were group-housed on a 12:12 light-dark cycle at $22{ }^{\circ} \mathrm{C}$ with free access to food and water. BALB/c mice, 20-25 g, were selected and divided into different groups. Mice without any treatment were used as the control group. Mice were fasted $12 \mathrm{~h}$ with free access to water before liver ischemic surgery. First, the mice were anesthetized by intraperitoneal injection of $3 \%$ pelltobarbitalum natricum $\left(80 \mathrm{mg} \mathrm{kg} \mathrm{kg}^{-1}\right)$ dissolved in saline, then the abdomens of mice were shaved and disinfected used $75 \%$ ethanol. Left and middle lobe liver were separated after dissection of the abdominal cavity; to close the portal vein and hepatic artery, we used a non-invasive vascular clip. After $0.5 \mathrm{~min}$, the whitened left and middle lobe liver was observed to certify that liver ischemia was successful. Persistent ischemia was maintained for $0.5 \mathrm{~min}, 5 \mathrm{~min}, 10 \mathrm{~min}, 30 \mathrm{~min}$ and $60 \mathrm{~min}$, then ischemic liver tissue was dissected into frozen sections. The entire process of mouse ischemia was conducted on a $37{ }^{\circ} \mathrm{C}$ heating plate. Afterward, the liver ischemia tissue sections were treated with $5 \mu \mathrm{M}$ Cy-HOCl for $30 \mathrm{~min}$ and washed with PBS buffer $(\mathrm{pH}=7.4)$ to remove excess $\mathrm{Cy}-\mathrm{HOCl}$. Then, the sections were imaged under a laser scanning confocal microscope.

\section{Results and discussion}

\subsection{Design strategies for probes Cy-HOCl}

The synthetic approach of fluorescence probe $\mathrm{Cy}-\mathrm{HOCl}$ is outlined in Scheme 1. The synthetic details of compounds were discussed in the Experimental section. All compounds were characterized by ${ }^{1} \mathrm{H}$ NMR, ${ }^{13} \mathrm{C}$ NMR and MS. A heptamethine cyanine dye was employed as the fluorophore unit to emit the detection signal located in the near-infrared region (NIR). Due to extremely low tissue auto-fluorescence and absorption in the NIR spectral range, optical imaging with NIR fluorophores shows high sensitivity and deep tissue penetration. In previous work, we found that the oxidative cyclization reaction of 4-amino-3-nitrophenyl with $\mathrm{HOCl}$ was highly rapid and specific. ${ }^{42}$ Based on this molecule, 4 -amino3-nitrophenol was chosen as the response group conjugated to the fluorophore unit to obtain the HOCl detection probe. The integration of 4-amino-3-nitrophenol into the fluorescence platform quenches the fluorescence of the fluorophore. The mechanism for this fluorescence quenching is a photoinduced electron transfer (PET) process from the excited fluorophore to a strong electron-withdrawing group (donor-excited PET; dPET). ${ }^{43,44}$ Finally, we obtained new probe $\mathrm{Cy}-\mathrm{HOCl}$ for detection of $\mathrm{HOCl}$ by oxidative cyclization reaction. The reaction between $\mathrm{Cy}-\mathrm{HOCl}$ and $\mathrm{HOCl}$ results in the 4-amino-3-nitrophenyl group being released as a leaving group. This ends the PET effect and induces recovery of fluorescence. The proposed detection mechanism is outlined in Scheme 2. Using this probe, we could real-time monitor the fluctuation of $\mathrm{HOCl}$ in living cells and in vivo during hypoxic stress.

\subsection{Spectroscopic properties}

We investigated the spectral response of $\mathrm{Cy}-\mathrm{HOCl}$ toward $\mathrm{HOCl}$ under simulated physiological conditions (10 mM HEPES buffer, $\mathrm{pH}=7.4)$. The maximum absorption wavelengths of the probe

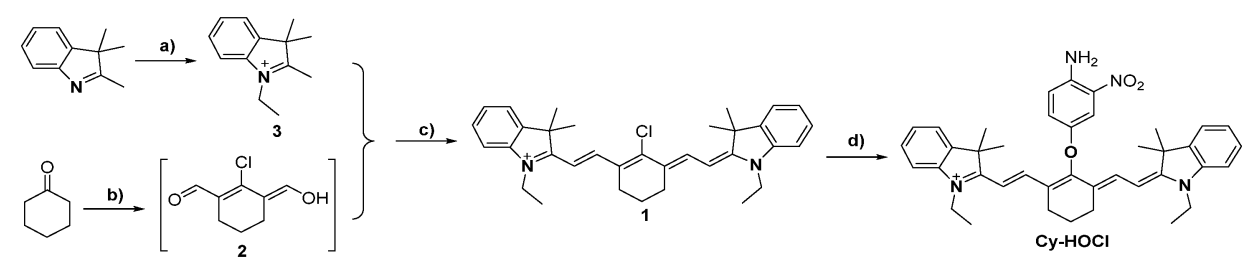

Scheme 1 The synthetic route of probe $\mathrm{Cy}-\mathrm{HOCl}$. (a) lodoethane, acetonitrile, refluxed $12 \mathrm{~h}, 90 \%$; (b) $\mathrm{DMF}, \mathrm{CH}_{2} \mathrm{Cl}_{2}, \mathrm{POCl}_{3}, 45{ }^{\circ} \mathrm{C}, 3 \mathrm{~h}, 85 \%$; (c) $V_{n \text {-butyl }}$ alcohol $/ V_{\text {benzene }}=7: 3$, refluxed $3 \mathrm{~h}, 70 \%$; (d) $\mathrm{NaH}, 4$-amino-3-nitrophenol, DMF, $25^{\circ} \mathrm{C}, 24 \mathrm{~h}, 50 \%$. 


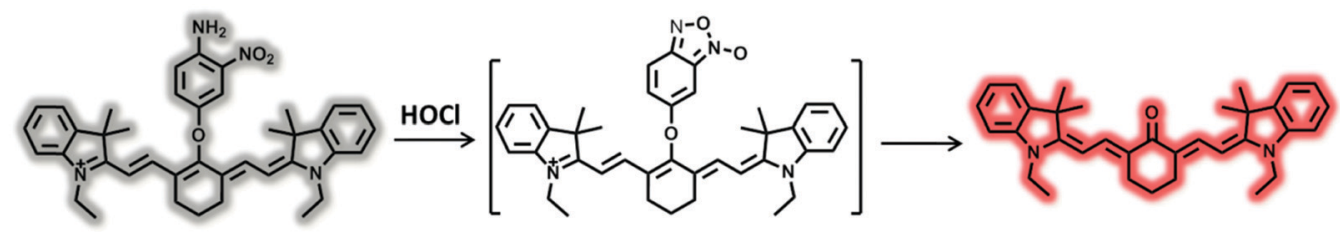

Scheme 2 Proposed detection mechanism of probe against $\mathrm{HOCl}$.
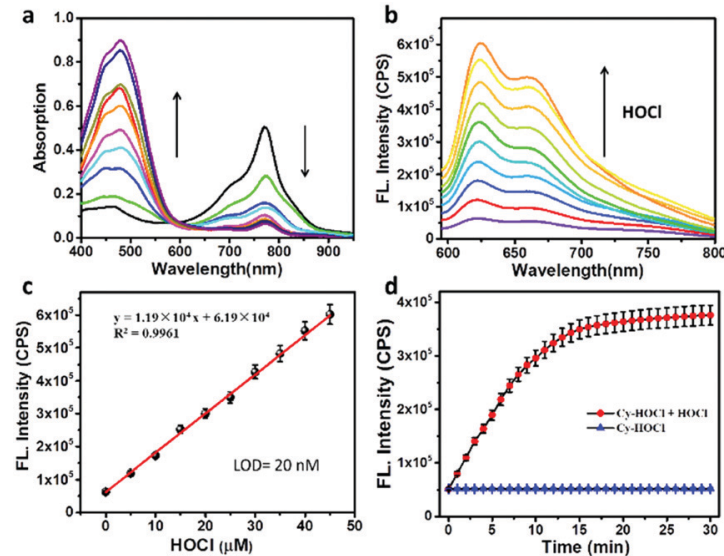

Fig. 1 Spectral properties of $\mathrm{Cy}-\mathrm{HOCl}$. (a) Absorption spectral changes of $\mathrm{Cy}-\mathrm{HOCl}(10 \mu \mathrm{M})$ in the presence of various concentrations of $\mathrm{NaClO}(0,5$, $10,15,20,25,30,35,40$ and $45 \mu \mathrm{M})$ in HEPES $(\mathrm{pH} 7.4,10 \mathrm{mM})$ at $37^{\circ} \mathrm{C}$ (b) Fluorescence emission spectral changes of $\mathrm{Cy}-\mathrm{HOCl}(10 \mu \mathrm{M})$; spectra were acquired $10 \mathrm{~min}$ after addition of various concentrations of $\mathrm{NaClO}$ $(0-45 \mu \mathrm{M})$. (c) The plot of the linear relationship between fluorescence intensities and $\mathrm{NaClO}$ concentrations $(0-45 \mu \mathrm{M}$ ). (d) Plot of fluorescence intensity of $\mathrm{Cy}-\mathrm{HOCl}(10 \mu \mathrm{M})$ vs. reaction time in the presence of $30 \mu \mathrm{M}$ $\mathrm{NaClO}$. Data were obtained at $\lambda_{\mathrm{ex}}=543 \mathrm{~nm}, \lambda_{\mathrm{em}}=625 \mathrm{~nm}$.

Cy-HOCl locate at $480 \mathrm{~nm}$ and $780 \mathrm{~nm}$ (Fig. 1a). In the presence of $\mathrm{Cy}-\mathrm{HOCl}$ and $\mathrm{HOCl}, \mathrm{Cy}-\mathrm{HOCl}$ exhibited a significant decline at the wavelength of $780 \mathrm{~nm}$. Simultaneously, obvious enhancement of the absorption peak at $480 \mathrm{~nm}$ was caused by the addition of HOCl. The fluorescence spectra of $\mathrm{Cy}-\mathrm{HOCl}$ were next measured to investigate the fluorescence response of the probe towards HOCl. As shown in Fig. 1b, the addition of HOCl (from 0 to $45 \mu \mathrm{M}$ ) triggered the increase of NIR fluorescence emission centered at $625 \mathrm{~nm}$; therefore, the emission at $625 \mathrm{~nm}$ was selected as the optimal fluorescence intensity for quantifying the fluorescence response of our probe to HOCl. The calibration curve is shown in Fig. 1c. There exists a good linearity with the concentration of $\mathrm{HOCl}$ ranging from $0-45 \mu \mathrm{M}$. The regression equation was $F_{625 \mathrm{~nm}}=1.19 \times 10^{4}[\mathrm{HOCl}](\mu \mathrm{M})+$ $6.19 \times 10^{4}(r=0.9961)$. Under the given experimental conditions, the limit of detection ( $3 \sigma /$ slope) toward $\mathrm{HOCl}$ was determined to be $10 \mathrm{nM}$. The results suggested that $\mathrm{Cy}-\mathrm{HOCl}$ had high sensitivity for $\mathrm{HOCl}$. The probe $\mathrm{Cy}-\mathrm{HOCl}$ has potential for application in bioassays.

\subsection{Kinetic Investigations of $\mathrm{Cy}-\mathrm{HOCl}$ toward $\mathrm{HOCl}$}

Due to the rapid metabolism and unstable properties of $\mathrm{HOCl}$ in biological systems, immediate response offers the possibility of direct detection without cumbersome pretreatment processes.
The activity of $\mathrm{HOCl}$ toward the reaction of $\mathrm{Cy}-\mathrm{HOCl}$ was assessed. Fluorescence kinetic curves of $\mathrm{Cy}-\mathrm{HOCl}$ with $\mathrm{HOCl}$ (at the concentration of $30 \mu \mathrm{M}$ ) for $30 \mathrm{~min}$ are depicted in Fig. 1d. The probe showed a fast response rate and a large fluorescence enhancement. The fluorescence signal reached a plateau in about $15 \mathrm{~min}$. But no obvious fluorescence signal change was observed with $\mathrm{HOCl}$ absent, which demonstrated that $\mathrm{Cy}-\mathrm{HOCl}$ is stable in the reaction system. The results illustrated that our probe could respond to $\mathrm{HOCl}$. The fast reaction kinetics are conducive to real-time detection in cells and in vivo.

\subsection{Selectivity of probe for HOCl}

We next tested the fluorescent response of Cy-HOCl to other physiologically related species in HEPES buffer solution (10 mM, pH 7.4). As illustrated in Fig. S1 (ESI $\dagger$ ), the probe was incubated with various biospecies, such as $S$-nitrosoglutathione (GSNO), $\mathrm{ONOO}^{-}$, $\mathrm{NO}$ (NOC-5), $\mathrm{NO}_{2}{ }^{-}$, tocopherols, $\mathrm{H}_{2} \mathrm{O}_{2}, \mathrm{O}_{2}{ }^{\bullet-}$, methyl linoleate hydroperoxide, $\mathrm{Na}_{2} \mathrm{~S}_{4}$ (a donor of $\mathrm{H}_{2} \mathrm{~S}_{n}$ ), L-cysteine (L-cys), glutathione (GSH), NaHS, ascorbic acid, L-arginine (L-arg), tyrosine, hydroxylamine (HA) and $\mathrm{HOCl}$. The fluorescence intensities were obtained. No obvious fluorescence signal changes were observed in the present of these interfering species without HOCl. Only HOCl offered a remarkable increase of fluorescence emission. Our results indicated that $\mathrm{Cy}-\mathrm{HOCl}$ possessed excellent selectivity toward $\mathrm{HOCl}$ in the presence of various biologically relevant species under physiological conditions.

\subsection{Fluorescence imaging of HOCl in living cells}

Since Cy-HOCl showed strong ability in detecting HOCl under simulated physiological conditions, we next assessed whether $\mathrm{Cy}-\mathrm{HOCl}$ was sensitive enough to monitor physiologically relevant levels of $\mathrm{HOCl}$ in living cells. Before that, it was inevitable to check its biocompatibility. Cy-HOCl showed low cytotoxicity toward LO2 human hepatocytes, as determined via MTT assays with $\mathrm{IC}_{50}$ of $360 \mu \mathrm{M}$ (Fig. S2, ESI $\dagger$ ). The results showed that Cy-HOCl could be applied for long-time cell imaging.

We applied $\mathrm{Cy}-\mathrm{HOCl}$ to estimate the changes of HOCl levels in cells. Before imaging, all cells were incubated with $\mathrm{Cy}-\mathrm{HOCl}$ for $30 \mathrm{~min}$, then washed with Dulbecco's Modified Eagle Medium (DMEM) 3 times. The intracellular fluorescence shown in Fig. 2a is very weak. If the cells were pretreated with NaClO to increase the exogenous $\mathrm{HOCl}$, there was strong fluorescence, as seen in Fig. 2b. The results certified that our probe is adequate to detect exogenous $\mathrm{HOCl}$ directly in living cells. $\mathrm{LO} 2$ cells were stimulated with lipopolysaccharide (LPS) for $16 \mathrm{~h}$ to induce ROS (including HOCl) expression. ${ }^{4,46}$ As expected, obvious 


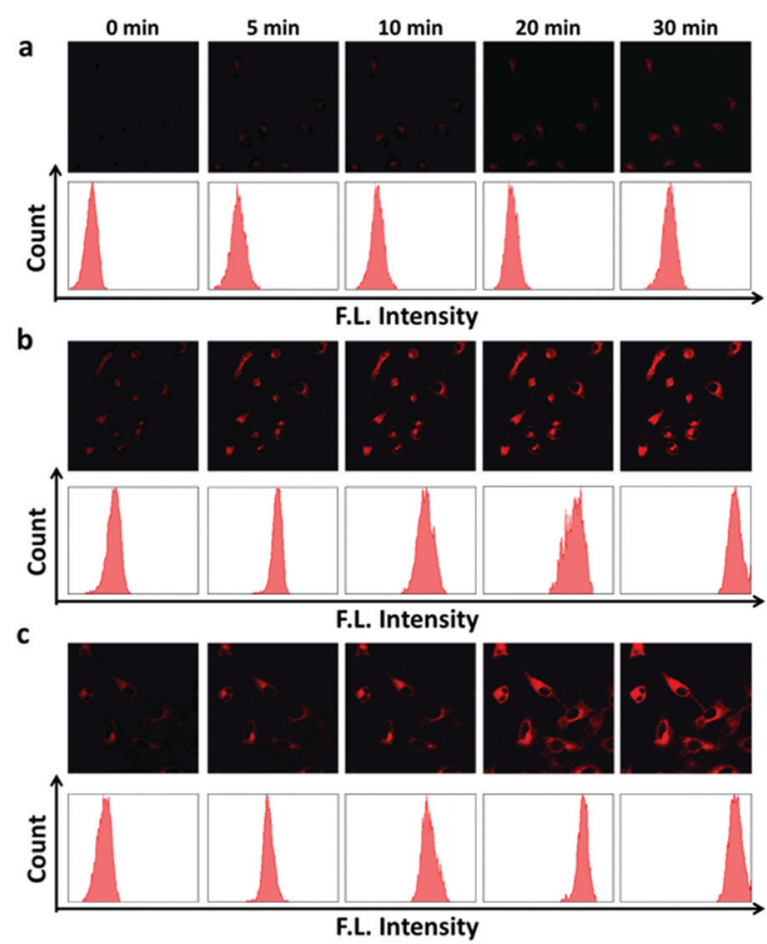

Fig. 2 Fluorescence imaging and flow cytometry assay in living LO2 cells to detect exogenous and endogenous $\mathrm{HOCl}$ with $\mathrm{Cy}-\mathrm{HOCl}(5 \mu \mathrm{M})$, after washing with DMEM to remove the redundant probe. Images display emission collected from 600 to $700 \mathrm{~nm}$ upon excitation at $543 \mathrm{~nm}$. (a) LO2 cells incubated with $\mathrm{Cy}-\mathrm{HOCl}$ as control. (b) LO2 cells incubated with $\mathrm{Cy}-\mathrm{HOCl}$ manipulated as in (a), then treated with $50 \mu \mathrm{M} \mathrm{NaClO}$ for $15 \mathrm{~min}$ for imaging. (c) LO2 cells stimulated with $1 \mu \mathrm{g} \mathrm{mL} \mathrm{L}^{-1}$ LPS for $16 \mathrm{~h}$, then incubated with $\mathrm{Cy}-\mathrm{HOCl}$ for 15 min for imaging.

fluorescence intensity was acquired (Fig. 2c). In addition, flow cytometry studies were performed to further confirm the results. These results indicated that our probe had potential to detect endogenous $\mathrm{HOCl}$ in living cells. Taken together, these data indicate that our probe $\mathrm{Cy}-\mathrm{HOCl}$ is suitable to real-time monitoring of exogenous and endogenous $\mathrm{HOCl}$ in living cells.

\subsection{Change of HOCl under hypoxia stress}

Appropriate oxygen supply sustains normal cellular activities, while hypoxia results in a series of physiological dysfunctions. Hypoxic stress is accompanied by the apparent increase of lipid peroxides, oxygen radicals, and some non-radical derivatives of oxygen $\left(\mathrm{O}_{2}\right)$ such as hypochlorous acid $(\mathrm{HOCl})$, which cause inactivation of proteins and consequently severe damage to cells. We performed assays in cells to explore how HOCl fluctuated under hypoxic stress. Next, we applied the probe to examine intracellular $\mathrm{HOCl}$ changes under different $\mathrm{O}_{2}$ levels. LO2 cells in Fig. 3a were cultured under hypoxic conditions with $20 \%, 10 \%, 5 \%, 1 \%$, and $0.1 \% \mathrm{O}_{2}$ for $4 \mathrm{~h}$. Strong fluorescence images were obtained from cells cultured with $1 \%$ and $0.1 \% \mathrm{O}_{2}$, while the fluorescence signal was obviously weaker under $10 \%$ and $20 \% \mathrm{O}_{2}$. The degrees of hypoxia positively correlated with fluorescence intensities of $\mathrm{Cy}-\mathrm{HOCl}$, clarifying that the stress response of $\mathrm{HOCl}$ was strongly dependent on oxygen levels. Flow cytometry studies were performed to

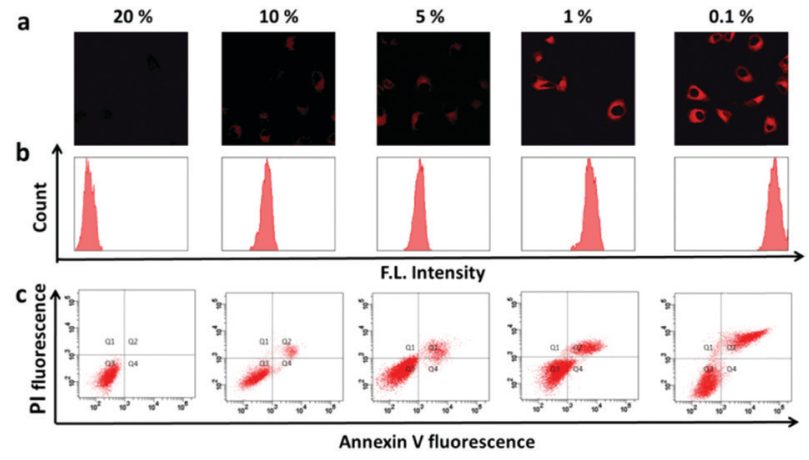

Fig. 3 Confocal microscopy images and flow cytometry assay of LO2 cells for evaluating $\mathrm{HOCl}$ fluctuation under hypoxic stress. All cells were incubated with $\mathrm{Cy}-\mathrm{HOCl}(5 \mu \mathrm{M})$ for $15 \mathrm{~min}$, then washed with DMEM to remove excess probe. (a) Fluorescence imaging of LO2 cells under hypoxic conditions with $20 \%, 10 \%, 5 \%, 1 \%$, and $0.1 \% \mathrm{O}_{2}$ for $4 \mathrm{~h}$. (Emission from 600 to $700 \mathrm{~nm}$ upon excitation at $543 \mathrm{~nm}$.) (b) Flow cytometry under the conditions in part (a). (c) Apoptosis analysis of LO2 cells under hypoxic stress. (Q1) Necrotic, (Q2) Late apoptosis, (Q3) Viable, (Q4) Early apoptosis.

confirm the results, seen in Fig. 3b. These data demonstrated that our probe could be applied to real-time detection of hypoxia-induced $\mathrm{HOCl}$ changes in living cells. The phenomena were attributed to cellular stress response caused by hypoxia. This redox imbalance causes cell apoptosis. To access the apoptosis, we performed PE Annexin V/7-AAD assay under different degrees of hypoxia. As indicated in Fig. 3c, the cells cultured under $20 \%, 10 \%, 5 \%, 1 \%$, and $0.1 \% \mathrm{O}_{2}$ had apoptosis rates of $0 \%, 9.5 \%, 20.4 \%, 42.6 \%$ and $65.5 \%$, respectively. The data revealed that hypoxia accelerated cell apoptosis.

\subsection{Imaging $\mathrm{HOCl}$ in acute ischemia zebrafish model}

Among the variety of animal models used to evaluate $\mathrm{HOCl}$, zebrafish are an attractive model for biocompatibility, toxicity, biodistribution, teratogenicity, immune response, and longterm effect studies. ${ }^{47-49}$ Zebrafish is a vertebrate model, with $99 \%$ embryonic essential genes conserved in humans. ${ }^{50}$ The ease of acquisition of zebrafish embryos from fertile adults, their small embryo size, and their optical transparency make it a suitable model for assessment of fluorescent dyes using standard imaging microscope. ${ }^{51}$ Novel fluorescent dyes can be applied to satisfy properties such as brightness and photostability of fluorescent signals detected through living tissues during whole embryo imaging. ${ }^{52}$ As mentioned above, however, no research has been reported to visualize $\mathrm{HOCl}$ in zebrafish under hypoxic stress during their early development. On the basis of the remarkable performance of probe $\mathrm{Cy}-\mathrm{HOCl}$, here we make such an attempt. We employed $\mathrm{Cy}-\mathrm{HOCl}$ to examine the changes of $\mathrm{HOCl}$ in a zebrafish model under hypoxic stress. Zebrafish were grown in E3 embryo media under different hypoxic conditions of $20 \%, 10 \%, 5 \%$, and $1 \% \mathrm{O}_{2}$ for $4 \mathrm{~h}$. For fluorescence imaging experiments, zebrafish were incubated with $5 \mu \mathrm{M}$ of Cy-HOCl in E3 embryo media for $30 \mathrm{~min}$ at $28{ }^{\circ} \mathrm{C}$, then washed with $\mathrm{PBS}(\mathrm{pH}$ 7.4) to remove the remaining Cy-HOCl. Finally, we obtained the fluorescence images of zebrafish under hypoxic stress. As shown as Fig. 4, the results of the 

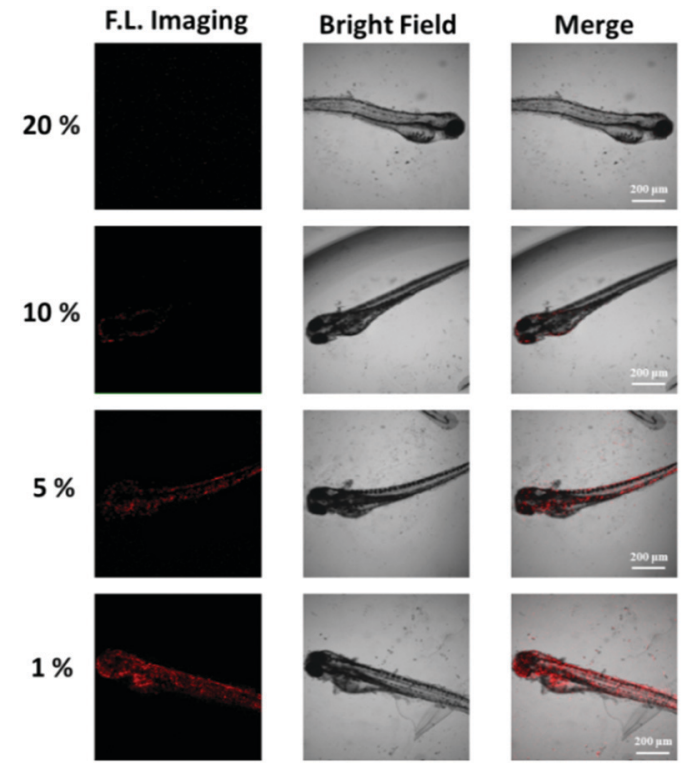

Fig. 4 Fluorescence images for monitoring $\mathrm{HOCl}$ generation during hypoxic stress in zebrafish via $\mathrm{Cy}-\mathrm{HOCl}$. The zebrafish were pretreated with $20 \%, 10 \%, 5 \%$, and $1 \% \mathrm{O}_{2}$ for $4 \mathrm{~h}$, then incubated with $\mathrm{Cy}-\mathrm{HOCl}(5 \mu \mathrm{M})$ for $30 \mathrm{~min}$ at $28{ }^{\circ} \mathrm{C}$ and washed with PBS (pH 7.4) to remove the remaining $\mathrm{Cy}-\mathrm{HOCl}$. The emission was collected from 600 to $700 \mathrm{~nm}$ upon excitation at $543 \mathrm{~nm}$. fluorescence intensities were all in the order of group $1 \%>$ $5 \%>10 \%>20 \% \mathrm{O}_{2}$. These results illustrated that $\mathrm{HOCl}$ should be rapidly released under hypoxic stress.

\subsection{Imaging $\mathrm{HOCl}$ in acute ischemia mice model}

Ischemia of organs blocks blood supply and results in deficiency of $\mathrm{O}_{2}$, which affects the normal functions of cells and organs. The pathogenesis of acute ischemia involves various mechanisms, including excessive production of ROS. Once acute ischemia happens, these ROS irreversibly damage biomacromolecules, which leads to cell dysfunction. We next employed Cy-HOCl to examine the changes of $\mathrm{HOCl}$ in the mouse model of acute liver ischemia. First, the mice were intravenously injected with Cy-HOCl $(5 \mu \mathrm{M}, 50 \mu \mathrm{L}$ in 1:9 DMSO/ saline $\mathrm{v} / \mathrm{v}$ ) for $1 \mathrm{~h}$. Then, the models were divided into five groups with different ligation times of portal vein and hepatic artery, $0 \mathrm{~min}$ (as control), $5 \mathrm{~min}, 15 \mathrm{~min}, 30 \mathrm{~min}$, and $60 \mathrm{~min}$, to induce acute liver ischemia. The mice without vessel ligation were set as control. As displayed in Fig. 5a, fluorescence images were obtained using this in vivo imaging system. As expected, the fluorescence signals of HOCl rapidly increased with the extension of liver ischemia time and saturated at the time point of $60 \mathrm{~min}$. The result demonstrated that $\mathrm{HOCl}$ is steeply released during acute liver ischemia. The changes of pathological morphology of liver
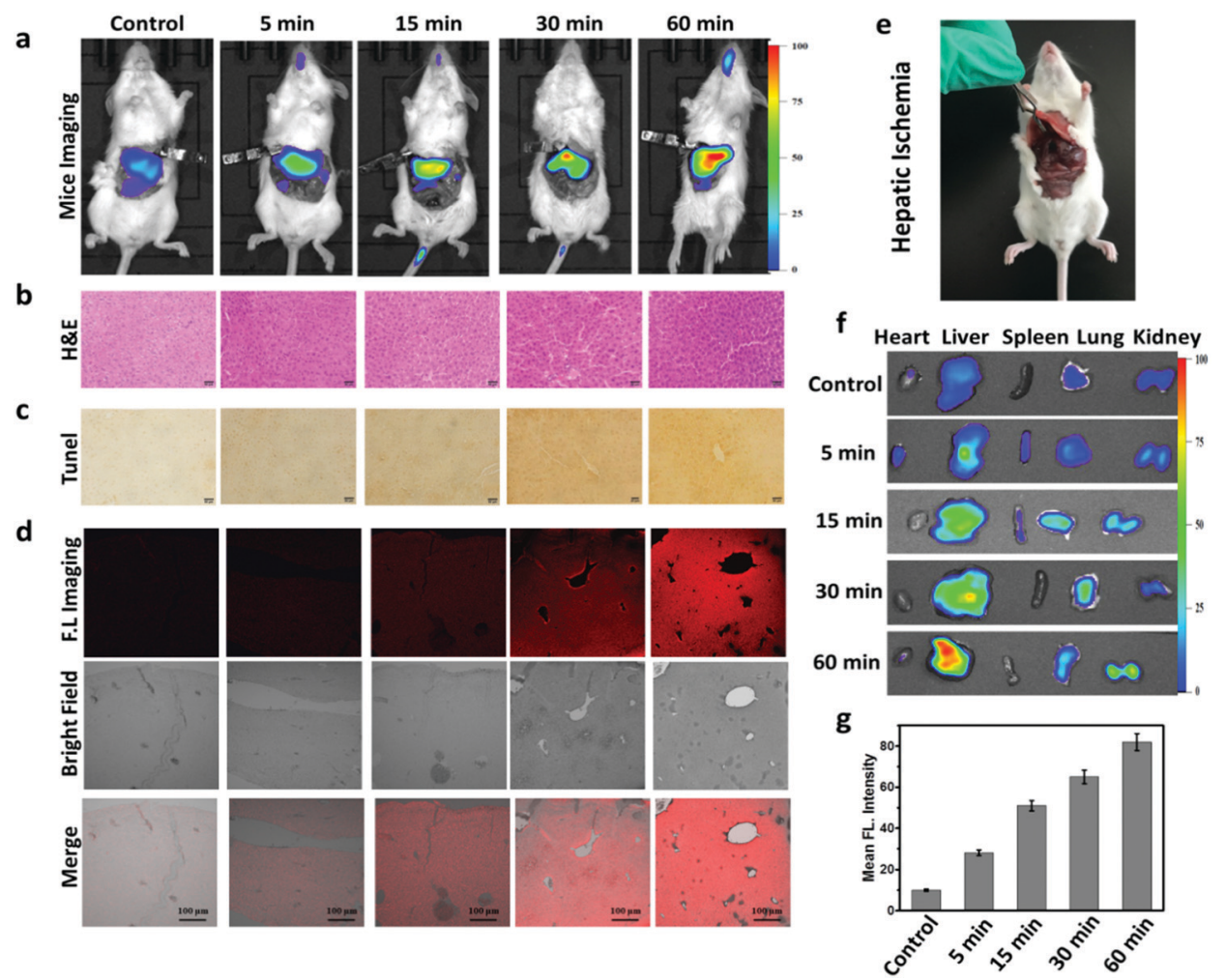

Fig. 5 Evaluation of $\mathrm{HOCl}$ in mouse model of acute liver ischemia via $\mathrm{Cy}-\mathrm{HOCl}$ within $60 \mathrm{~min}$. The mice in each group were intravenously injected with $\mathrm{Cy}-\mathrm{HOCl}(5 \mu \mathrm{M}, 50 \mu \mathrm{L}$ in $1: 9 \mathrm{DMSO} /$ saline v/v) for $1 \mathrm{~h}$ prior to testing. The emission was collected from 600 to $700 \mathrm{~nm}$ upon excitation at $543 \mathrm{~nm}$. (a) The fluorescence images of acute liver ischemia mice with different ligation times. (b and c) H\&E sections and TUNEL staining of liver tissue. (d) Fluorescence images of liver tissue section by laser scanning confocal microscope. (e) The details of the portal vein and hepatic artery ligation. (f) The fluorescence images of isolated organs in acute liver ischemia mice (heart, liver, spleen, lung, and kidney). (g) Mean fluorescence intensities of $\mathrm{Cy}$ - $\mathrm{HOCl}$ in livers of (a). Data are presented as mean \pm SD $(n=5)$. 
tissue were checked using H\&E sections (Fig. 5b) and TUNEL staining (Fig. 5c). As ligation time lengthened, the $\mathrm{HOCl}$ fluorescence imaging of liver tissue sections showed the enhanced fluorescence signal in Fig. 5d. The details of the organ ligation are shown in Fig. 5e. As seen in Fig. 5f, we obtained gradual enhancement of fluorescence signal over time in isolated liver tissue. The corresponding quantitative fluorescence data are shown in Fig. 5g. Over all, the high sensitivity and rapid response time made our probe a possible chemical tool for real-time detection of changes of $\mathrm{HOCl}$ in an acute liver ischemic mouse model.

\section{Conclusions}

In summary, we synthesized a NIR fluorescent probe, $\mathrm{Cy}-\mathrm{HOCl}$, for $\mathrm{HOCl}$ detection in living cells and in vivo under hypoxic stress. The probe is sensitive and biocompatible, allowing fluorescence imaging of exogenous and endogenous $\mathrm{HOCl}$ in living cells. We detected the changes of HOCl in living cells under hypoxic stress, as well as in zebrafish under different hypoxic conditions. Acute liver ischemia models of mice were established to evaluate the biological effects of HOCl under hypoxia stress. H\&E coloring, TUNEL coloring and fluorescence imaging of liver tissue of hypoxic mice were acquired to observe the liver damage and change of HOCl. All the results revealed that $\mathrm{HOCl}$ increases under hypoxic stress both in living cells and in vivo and hypoxic stress can injure cells and tissue from oxidative damage. Our research provides evidence that HOCl may be a novel factor for hypoxia-induced injury. The new probe offers a useful tool to better detect the physiological and pathological bioroles of $\mathrm{HOCl}$ in cells and in vivo.

\section{Conflicts of interest}

There are no conflicts to declare.

\section{Acknowledgements}

We thank the National Nature Science Foundation of China (No. 21575159, 81573393, 21575080), the program of Youth Innovation Promotion Association, CAS (Grant 2017256, 2019217), the National Research Foundation of Korea supported this work (2017M3D1A1039287, 2018M3A7B4071203) and the Instrument Developing Project of the Chinese Academy of Sciences (YZ201662).

\section{References}

1 T. L. Clanton, J. Appl. Physiol., 2007, 102, 2379-2388.

2 M. Valko, C. J. Rhodes, J. Moncol, M. Izakovic and M. Mazur, Chem. -Biol. Interact., 2006, 160, 1-40.

3 E. E. Battin and J. L. Brumaghim, Cell Biochem. Biophys., 2009, 55, 1-23.

4 D. Lapenna and F. Cuccurullo, Gen. Pharmacol., 1996, 27, 1145-1147.

5 T. Ozben, J. Pharm. Sci., 2007, 96, 2181-2196.

6 C. C. Winterbourn, Nat. Chem. Biol., 2008, 4, 278-286.
7 C. J. van Dalen, M. W. Whitehouse, C. C. Winterbourn and A. J. Kettle, Biochem. J., 1997, 327, 487-492.

8 Y. W. Yap, M. Whiteman and N. S. Cheung, Cell. Signalling, 2007, 19, 219-228.

9 C. L. Hawkins, D. I. Pattison and M. J. Davies, Amino Acids, 2003, 25, 259-274.

10 S. Hammerschmidt, N. Buchler and H. Wahn, Chest, 2002, 121, 573-581.

11 T. Hasegawa, E. Malle, A. Farhood and H. Jaeschke, Am. J. Physiol.: Gastrointest. Liver Physiol., 2005, 289, G760-G767.

12 B. Halliwell and M. Wasil, J. Rheumatol., 1988, 15, 530.

13 R. Zhang, M. L. Brennan, X. Fu, R. J. Aviles, G. L. Pearce, M. S. Penn, E. J. Topol, D. L. Sprecher and S. L. Hazen, JAMA, J. Am. Med. Assoc., 2001, 286, 2136-2142.

14 R. Zhang, B. Song and J. Yuan, TrAC, Trends Anal. Chem., 2018, 99, 1-33.

15 Y. Yue, F. Huo, C. Yin, J. O. Escobedo and R. M. Strongin, Analyst, 2016, 141, 1859-1873.

16 L. Yuan, W. Lin, Y. Xie, B. Chen and J. Song, Chemistry, 2012, 18, 2700-2706.

17 B. Zhu, L. Wu, M. Zhang, Y. Wang, C. Liu, Z. Wang, Q. Duan and P. Jia, Biosens. Bioelectron., 2018, 107, 218-223.

18 H. Xiao, K. Xin, H. Dou, G. Yin, Y. Quan and R. Wang, Chem. Commun., 2015, 51, 1442-1445.

19 L. Yuan, L. Wang, B. K. Agrawalla, S. J. Park, H. Zhu, B. Sivaraman, J. Peng, Q. H. Xu and Y. T. Chang, J. Am. Chem. Soc., 2015, 137, 5930-5938.

20 Q. Xu, C. H. Heo, J. A. Kim, H. S. Lee, Y. Hu, D. Kim, K. M. Swamy, G. Kim, S. J. Nam, H. M. Kim and J. Yoon, Anal. Chem., 2016, 88, 6615-6620.

21 H. J. Lee, M. J. Cho and S. K. Chang, Inorg. Chem., 2015, 54, 8644-8649.

22 P. Chen, Z. Zheng, Y. Zhu, Y. Dong, F. Wang and G. Liang, Anal. Chem., 2017, 89, 5693-5696.

23 Q. Xu, K. A. Lee, S. Lee, K. M. Lee, W. J. Lee and J. Yoon, J. Am. Chem. Soc., 2013, 135, 9944-9949.

24 J. J. Hu, N. K. Wong, M. Y. Lu, X. Chen, S. Ye, A. Q. Zhao, P. Gao, K. R. Yi-Tsun, J. Shen and D. Yang, Chem. Sci., 2016, 7, 2094-2099.

25 S. I. Reja, V. Bhalla, A. Sharma, G. Kaur and M. Kumar, Chem. Commun., 2014, 50, 11911-11914.

26 Q. Zhang, N. Zhang, Y. T. Long, X. Qian and Y. Yang, Bioconjugate Chem., 2016, 27, 341-353.

27 M. Emrullahoglu, M. Ucuncu and E. Karakus, Chem. Commun., 2013, 49, 7836-7838.

28 H. Zhu, J. Fan, J. Wang, H. Mu and X. Peng, J. Am. Chem. Soc., 2014, 136, 12820-12823.

29 G. Cheng, J. Fan, W. Sun, J. Cao, C. Hu and X. Peng, Chem. Commun., 2014, 50, 1018-1020.

30 J. J. Hu, N. K. Wong, Q. Gu, X. Bai, S. Ye and D. Yang, Org. Lett., 2014, 16, 3544-3547.

31 G. Cheng, J. Fan, W. Sun, K. Sui, X. Jin, J. Wang and X. Peng, Analyst, 2013, 138, 6091-6096.

32 J. T. Hou, K. Li, J. Yang, K. K. Yu, Y. X. Liao, Y. Z. Ran, Y. H. Liu, X. D. Zhou and X. Q. Yu, Chem. Commun., 2015, 51, 6781-6784. 
33 H. Feng, Z. Zhang, Q. Meng, H. Jia, Y. Wang and R. Zhang, Adv. Sci., 2018, 5, 1800397.

34 L. Cao, R. Zhang, W. Zhang, Z. Du, C. Liu, Z. Ye, B. Song and J. Yuan, Biomaterials, 2015, 68, 21-31.

35 F. Zhang, X. Liang, W. Zhang, Y. L. Wang, H. Wang, Y. H. Mohammed, B. Song, R. Zhang and J. Yuan, Biosens. Bioelectron., 2017, 87, 1005-1011.

36 Y. L. Pak, S. J. Park, G. Song, Y. Yim, H. Kang, H. M. Kim, J. Bouffard and J. Yoon, Anal. Chem., 2018, 90, 12937-12943.

37 Q. Duan, P. Jia, Z. Zhuang, C. Liu, X. Zhang, Z. Wang, W. Sheng, Z. Li, H. Zhu, B. Zhu and X. Zhang, Anal. Chem., 2019, 91, 2163-2168.

38 B. Zhu, L. Wu, M. Zhang, Y. Wang, Z. Zhao, Z. Wang, Q. Duan, P. Jia and C. Liu, Sens. Actuators, B, 2018, 263, 103-108.

39 B. Zhu, L. Wu, H. Zhu, Z. Wang, Q. Duan, Z. Fang, P. Jia, Z. Li and C. Liu, Sens. Actuators, B, 2018, 269, 1-7.

40 H. Zhang, R. Liu, Y. Tan, W. H. Xie, H. Lei, H. Y. Cheung and H. Sun, ACS Appl. Mater. Interfaces, 2015, 7, 5438-5443.

41 H. Li, L. Guan, X. Zhang, H. Yu, D. Huang, M. Sun and S. Wang, Talanta, 2016, 161, 592-598.

42 Y. Xiao, R. Zhang, Z. Ye, Z. Dai, H. An and J. Yuan, Anal. Chem., 2012, 84, 10785-10792.
43 R. Wang, F. Yu, L. Chen, H. Chen, L. Wang and W. Zhang, Chem. Commun., 2012, 48, 11757-11759.

44 T. Ueno, Y. Urano, H. Kojima and T. Nagano, J. Am. Chem. Soc., 2006, 128, 10640-10641.

45 T. Ida, T. Sawa, H. Ihara, Y. Tsuchiya, Y. Watanabe, Y. Kumagai, M. Suematsu, H. Motohashi, S. Fujii, T. Matsunaga, M. Yamamoto, K. Ono, N. O. Devarie-Baez, M. Xian, J. M. Fukuto and T. Akaike, Proc. Natl. Acad. Sci. U. S. A., 2014, 111, 7606-7611.

46 F. Yu, M. Gao, M. Li and L. Chen, Biomaterials, 2015, 63, 93-101.

47 S. Lin, Y. Zhao, A. E. Nel and S. Lin, Small, 2013, 9, 1608-1618.

48 J. W. Fan, R. Vankayala, C. L. Chang, C. H. Chang, C. S. Chiang and K. C. Hwang, Nanotechnology, 2015, 26, 215703.

49 Z. He, Y. Sun, J. Cao and Y. Duan, Phys. Chem. Chem. Phys., 2016, 18, 11986-11999.

50 A. Amsterdam, R. M. Nissen, Z. Sun, E. C. Swindell, S. Farrington and N. Hopkins, Proc. Natl. Acad. Sci. U. S. A., 2004, 101, 12792-12797.

51 S. K. Ko, X. Chen, J. Yoon and I. Shin, Chem. Soc. Rev., 2011, 40, 2120-2130.

52 F. Progatzky, M. J. Dallman and C. C. Lo, Interface Focus, 2013, 3, 20130001. 